\title{
THE RELEVANCE OF BURIAL TO EVADE ACORN PREDATION IN AN OAK FOREST AFFECTED BY HABITAT LOSS AND LAND USE CHANGES
}

\author{
Carlos Renato Ramos-Palacios and Ernesto I. Badano ${ }^{1}$ \\ División de Ciencias Ambientales, Instituto Potosino de Investigación Científica y Tecnológica, San Luis Potosí, \\ San Luis Potosí, Mexico \\ ${ }^{1}$ Corresponding author: ernesto.badano@ipicyt.edu.mx
}

\begin{abstract}
Seed burial has been proposed as an effective mechanism to evade predation in continuous forests. However, its relevance may be compromised in fragmented forests because: (1) predators are usually concentrated within forests patches, which elevates consumer pressure on seeds; and (2) fragmentation reduces seed production in remnant trees, decreasing food availability for seed consumers. Thus, predators might be forced to consume buried seeds after seeds on the soil surface are depleted. Indeed, they may explore the surrounding matrix in search of food when seeds within patches become scarce. This study assesses these issues in a fragmented oak forest where human activities have generated four habitat types: forest patches, patch edges, matrix habitat surrounding patches, and an abandoned agricultural field in the neighborhoods of the fragmented forest. In this landscape, we assessed what animals consume acorn and compared removal rates between buried acorns and acorns exposed on the soil surface across these habitat types. Mice of the genus Peromyscus and birds of the genus Aphelocoma were the main responsible of removing acorns in all habitats types, but mice were only recorded during night and birds were only recorded during day. Buried acorns were less removed (12-35\%) than exposed ones (42-68\%) in the matrix habitat and the abandoned field. Nevertheless, within forest patches and their edges, buried (78-81\%) and exposed acorns $(91 \%)$ showed no differences in removal rates. These results suggest that burial may be an effective mechanism to evade acorn predation in habitats strongly affected by human activities, while it would have little relevance within forest patches.
\end{abstract}

Keywords: birds, fragmentation, Mexico, mice, seed predation.

Resumen: El enterramiento de semillas es considerado un mecanismo efectivo para evadir la depredación en bosques continuos. Sin embargo, su importancia puede verse comprometida en bosques fragmentados debido a que: (1) los depredadores suelen concentrarse en los parches de bosque, lo que eleva la presión de consumo sobre las semillas; y (2) la fragmentación reduce la producción de semillas en los árboles remanentes, lo que disminuye la disponibilidad de alimentos para sus consumidores. Así, los depredadores podrían verse obligados a consumir semillas enterradas después de agotar las semillas en la superficie del suelo. De hecho, podrían incluso explorar el hábitat circundante en busca de comida cuando las semillas dentro de los parches escaseen. Este estudio se enfoca en estos temas en un encinar fragmentado, donde las actividades humanas generaron cuatro tipos de hábitats: el interior de los parches de bosque, sus bordes, la matriz de hábitat que rodea los parches, y un campo agrícola abandonado colindante al bosque fragmentado. En este paisaje se evaluó cuáles animales contribuyen a movilizar las bellotas, y se compararon las tasas de sustracción entre bellotas enterradas y expuestas en la superficie del suelo a través de esos tipos de hábitat. Ratones del género Peromyscus y aves del género Aphelocoma fueron detectados sustrayendo bellotas en todos los tipos de hábitats, pero los ratones sólo se registraron durante la noche mientras que las aves sólo se registraron durante el día. Las bellotas enterradas fueron menos sustraídas (12-35\%) que las expuestas (42-68\%) en el hábitat de la matriz y el campo abandonado. Sin embargo, dentro de los parches de bosque y sus bordes, las bellotas enterradas (78-81\%) y expuestas (91\%) no mostraron diferencias en sus tasas de sustracción. Estos resultados sugieren que el enterramiento puede ser un mecanismo eficaz para evadir la depredación de bellotas en hábitats fuertemente afectados por las actividades humanas, mientras que tendría poca relevancia dentro de los parches de bosque.

Palabras clave: aves, depredación de semillas, fragmentación, México, ratones.

$S_{a}^{\text {ast }}$ eed predators from forest ecosystems are intensely active after seed maturation and they may account for most seeds that reach the soil after primary dispersion (Crawley and Long, 1995; Kelly and Sork, 2002; Bonal et al., 2007; Herrerías-Diego et al., 2008; Vaz Ferreira et al., 2011). Therefore, the recruitment of those tree species that are 
deeply affected by seed consumers would depend upon the chance that some seeds might reach "safe sites" (Janzen, 1971; Andersen, 1989; García et al., 2005; Pinto et al., 2009). Several studies suggested that burial may help to evade seed predation, either when burial occurs spontaneously (e.g., the seeds reach fissures in the soil or are covered by sediments after rainfalls) or when it is performed by animals (e.g., scatter-hoarding granivores). Nevertheless, most studies supporting these proposals were conducted in continuous forest ecosystems where seed predators can move freely across the landscape (e.g., Crawley and Long, 1995; Hulme and Borelli, 1999; Cao et al., 2000; Perea et al., 2012). Consequently, in these landscapes, seed consumers constantly move in search of those food resources that are easier to accede (e.g., seed exposed on the soil surface), while they ignore buried seeds because prey manipulation time (i.e., the time required to accede and consume a seed) is higher (Sork, 1983; Hulme and Borelli, 1999).

The relevance of seed burial as a mechanism to evade predators, however, may be compromised in forest ecosystems affected by human activities, and this proposal is supported by two main arguments. On the one hand, seed consumers in fragmented forests preferentially feed at the interior of forest patches. Small mammals, for instance, focus their foraging activities within the patches and avoid moving across anthropogenic matrices because this later habitat offers scarce opportunities to evade their predators (Tellería et al., 1991; Nupp and Swihart, 2000; Rizkalla and Swihart, 2007). As a consequence of this behavior, seed consumers are concentrated within the patches and this elevates consumer pressure on seed banks, as compared to seed banks in the surrounding matrix habitat (Muñoz and Bonal, 2011). On the other hand, the environmental changes associated to forest fragmentation can dramatically reduce the reproductive success of trees within remnant patches (Rocha and Aguilar, 2001; Burgos et al., 2008; Vesk et al., 2010; Barbeta et al., 2011), and this could be translated in lower availability of food resources for seed consumers. In this latter scenario, and once consumers have depleted seed banks on the soil surface, pilferage of seeds that are already buried may start to occur within forest patches. Moreover, this scarcity of food resources within forest patches may also force seed consumers to explore the surrounding matrix habitat in search of new sources of food (Bustamante et al., 2012). By following these lines of reasoning, it can be proposed that seeds exposed on the soil surface should experience higher consumption rates than buried seeds at the interior of forest patches, and this would occur because exposed seeds are easier to find by consumers. However, pilferage of buried seeds should start within forest patches when seeds on the soil surface become scarce. This depletion of seed banks within forest patches may also obligate consumers to move across the matrix habitat in search of seeds, but seed consumption rates in this latter habitat must be lower than within the patches because the matrix implies high predation risks for seed consumers. Therefore, for fragmented forest ecosystems, we propose that consumption rates of seeds exposed on the soil surface, as well as of buried seeds, should decline from the interior of forest patches towards the matrix habitat surrounding them.

To test these hypotheses, we focused on a fragmented oak forest from central Mexico. We choose this study system because acorns are the primary source of food for seed consumers, particularly small mammals and granivorous birds, in oak-dominated forests (Smith and Stapanian, 2002; Steele and Smallwood, 2002; Steffen et al., 2002). Further, it is important to highlight that Mexico harbors the highest diversity of oak species in the world, but the constant expansion of the agricultural frontier has strongly reduced the cover of these forests (Lund et al., 2002; Badano, 2011). Therefore, understanding how seed consumers reduce acorn availability in fragmented oak ecosystems could provide valuable information that may contribute to the recovery of these forests. Taking into account these considerations, the aims of this study are (1) to determine whether consumption rates differ between acorns exposed on the soil surface and buried acorns, and (2) to assess whether these consumption rates differ across the habitat types comprising fragmented forests.

\section{Methods}

Study site and species description. This study was conducted in a fragmented oak forest located in the communal farm Monte Caldera ( $22^{\circ} 11^{\prime} 30^{\prime \prime} \mathrm{N}, 100^{\circ} 42^{\prime} 48^{\prime \prime} \mathrm{W}, 2,204 \mathrm{~m}$ a.s.l.), state of San Luis Potosí, Mexico. Climate in the study site is semiarid; average annual temperature is $16.8^{\circ} \mathrm{C}$, but it can surpass $38{ }^{\circ} \mathrm{C}$ in May and fall down below $-6{ }^{\circ} \mathrm{C}$ in January (Pedraza, 1994). Annual precipitation oscillates between 120 and $450 \mathrm{~mm}$, but most rainfall events are concentrated in summer (June-September). The rainy season is followed by a markedly dry season between October and May (Pedraza, 1994).

This site was originally covered by extensive oak forests, but trees were selectively felled to use them as fuel in the smelters of local mines of gold and silver between the $16^{\text {th }}$ and $18^{\text {th }}$ centuries (Studnicki-Gizbert and Schecter, 2010). Currently, the landscape of the study site is composed by disperse patches (approximately 70 patches located $20-30 \mathrm{~m}$ away each other) of the softwood oak Quercus laeta Liebm. (Fagaceae). These patches are immersed in a matrix of short grasses (10-30 cm tall) that were used for livestock grazing during the last 100 years (Martínez Chaves et al., 2010). Further, in the neighborhoods of this fragmented forest there is an extensive deforested area that was used for agricultural purposes during more than four centuries, but it was abandoned 40 years ago and is now covered by medium-tall grasses (40-50 cm tall). Therefore, three clearly distinctive habitat types can be distinguished in the study site: (1) 
the forest patches of $Q$. laeta, (2) their surrounding matrix habitat, and (3) the neighboring abandoned field. All these habitat types can influence the distribution and behavior of local seed consumers (McCormick and Meiners, 2000; Meiners and LoGiudice, 2003; Bustamante et al., 2012), causing differential predation rates on acorns. Additionally, because the bordering zone that binds forest patches to their surrounding matrix, namely the patches edges, can also influence the distribution and behavior of vertebrates that consume seeds (Fagan et al., 1999; Meiners and LoGiudice, 2003), this fourth habitat type was also included in this study.

Because Quercus laeta is the only tree species in the fragmented forest, this study focused on this oak species. This oak is endemic to Mexico (Llorente-Bousquets and Ocegueda, 2008); its bloom usually starts between May and June, and acorns are produced between September and February (Arizaga et al., 2009). Nevertheless, as occurs in most species of the genus Quercus, this oak has mast-seed production -i.e., the intermittent production of large crops of acorns spaced by several seasons of low or null seed production. For this reason, we regularly visited the study site during three consecutive years, from 2009 to 2011, and looked for acorns on trees and the soil beneath their canopy. No acorns were found on the soil surface, or on trees, in 2009 and 2010. Nevertheless, developing acorns were observed on most oaks in June 2011. Thus, for the experiment described below, mature acorns were collected from the branches of trees in October 2011, just before they were released. Further, by performing the experiment during a masting year, we could ensure that acorn consumers were active in the studied ecosystem.

Field experiment. A field experiment was conducted to estimate consumption rates of acorns exposed on the soil surface (hereafter, exposed acorns) and buried acorns across the different habitat types of this fragmented forest. For this, we randomly selected ten oak patches larger than $200 \mathrm{~m}^{2}$ and established a rectangular experimental plot of $2 \times 2 \mathrm{~m}$ at the center of each patch. After that, we extended a linear transect from the center of each patch towards the matrix habitat in a random cardinal direction. By using this procedure, we established two additional experimental plots corresponding to each patch; one of these plots was located in the site were the transect intercepted the patch edge, and the other plot was located $10 \mathrm{~m}$ away from the patch edge in the matrix habitat. For all plots located in the matrix habitat, we took care of maintaining a minimum distance of $10 \mathrm{~m}$ from the edge of any other patch to avoid confounding effects in our experimental design. Finally, ten experimental plots were also established in the abandoned field that neighbors the fragmented forest; all these plots were located $45 \mathrm{~m}$ away from any oak patch.

Experimental plots were partially cleared by removing grasses, rocks, and leaf litter in order to improve visibility of the soil. We also took care of removing all acorns in the surroundings of the plots ( $2 \mathrm{~m}$ around) to avoid their interference with the experiment, hence preventing potential biased effects across experimental plots. After that, a grid of 100 cells of $10 \times 10 \mathrm{~cm}$ was placed at the center of each experimental plot, so as a distance of $50 \mathrm{~cm}$ was maintained between the edge of the grid and the edge of the plot in all directions (Figure 1). Within the grid, we randomly selected 20 cells and dug a small cylindrical hole $(5 \mathrm{~cm}$ diameter $\times$ $10 \mathrm{~cm}$ deep) at the center of each of these cells. An acorn was deposited at the bottom of each hole and it was covered with soil. Since the acorns of Quercus laeta we collected were 6 $\mathrm{cm}$ length and $3 \mathrm{~cm}$ width, in average, their final burial depth was $3-4 \mathrm{~cm}$ once they were put in the holes; this mimics the typical burial depth at which scatter-hoarding rodents from temperate oak forest bury their acorns (Jacobs and Liman, 1991; Borchert and Tyler, 2010; Leverkus et al., 2013). Later, other 20 cells were randomly selected within the grid and an acorn was disposed on the soil surface of each of these cells. Therefore, each experimental plot contained $20 \mathrm{bu}-$ ried acorns and 20 exposed acorns, which were offered to local seed consumers during the experiment (Figure 1). This

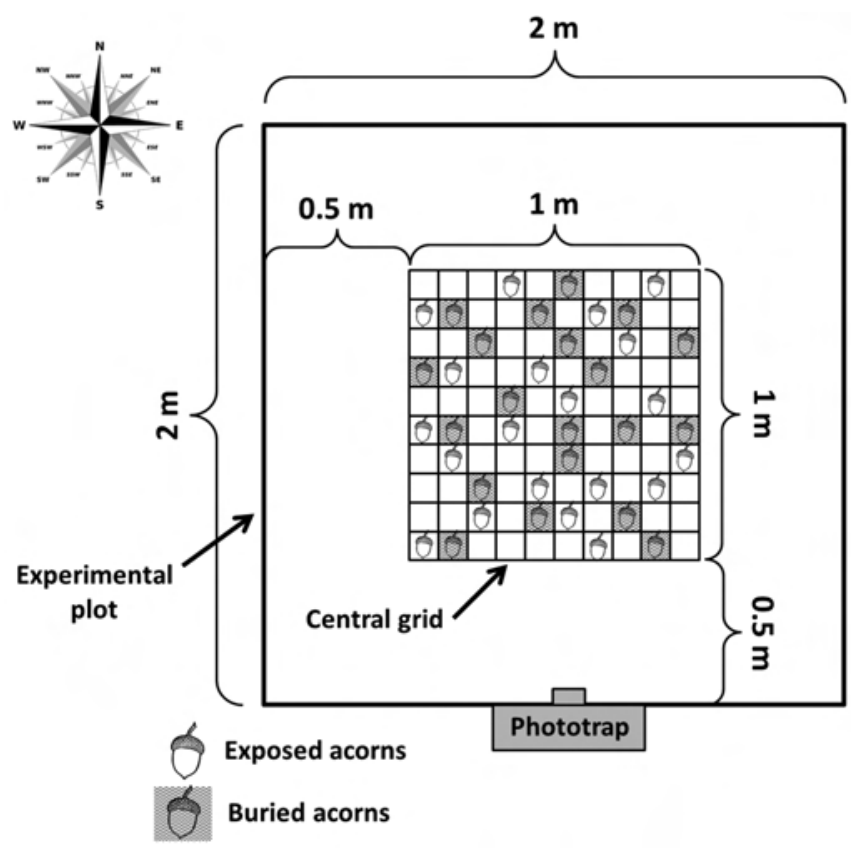

Figure 1. Schematic design of experimental plots used in the field experiment to assess acorn removal rates. Each experimental plot consisted in a $1 \times 1 \mathrm{~m}$ grid containing 100 cells of $10 \times 10 \mathrm{~cm}$ that was located within a $2 \times 2 \mathrm{~m}$ quadrat that was previously cleared. Each of these plot contained 20 buried acorns and 20 acorns on the soil surface that were randomly distributed across the cells of the grid. To assess what vertebrates consume acorns in the study site, a phototrap was disposed on the north-facing side of two experimental plots per habitat type (patch interior, patch edge, matrix habitat surrounding the patches, and the abandoned field that neighbors the fragmented forest). 

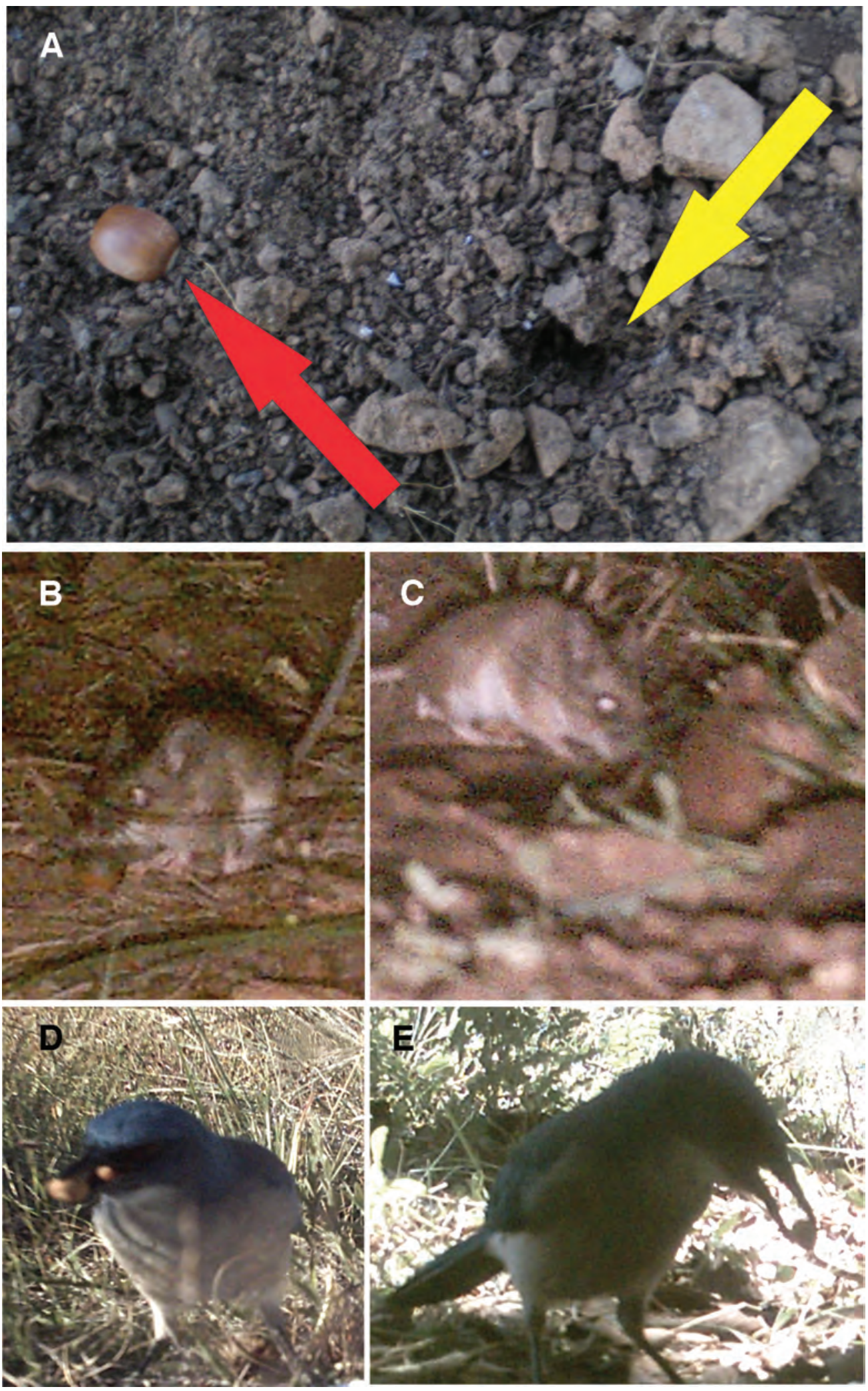

Figure 2. The upper panel of the figure (A) shows the detail of a hole practiced by seed consumers to reach buried acorns (indicated with a yellow arrow). For illustrative purposes, an acorn on the soil surface is shown on the left side of this picture (indicated with a red arrow). The lower panels of this figure are close-ups of the acorn consumers captured with phototraps, including mice of the genus Peromyscus $(\mathrm{B}, \mathrm{C})$ and birds of the genus Aphelocoma $(\mathrm{D}, \mathrm{E})$. 
procedure was repeated in all experimental plots, resulting in 200 buried acorns and 200 exposed acorns at each habitat type.

To assess what vertebrates may feed acorns in the study site, two experimental plots were randomly selected at each habitat type and a phototrap (STC-TGL5M Digital Scouting Camera, Stealth Cam, USA) was fixed on the north-facing side of these plots. Phototrap cameras were adjusted to maximum resolution (5 megapixels) and movement sensors were adjusted to maximum sensitivity. Further, because phototraps are equipped with flashes and clocks, they were programed to take both diurnal and nocturnal photographs, as well as to record the hour at which each picture was taken.

This experiment was started on October $25^{\text {th }} 2011$ at 12:00 h, and experimental plots were visited each $6 \mathrm{~h}$ during six consecutive days. At each monitoring time (00:00, 06:00, 12:00 and 18:00), we counted the amount of buried and exposed acorns that were removed from experimental plots. Removal of exposed acorns was assumed when they were no longer present within the experimental plot. On the other hand, pilferage of acorn beneath the soil surface was assumed when a small hole was observed in the site where the acorn was buried (Figure 2A). These data allowed us to estimate removal rates of buried and exposed acorns at the different habitat types (i.e., patch interior, patch edge, the matrix surrounding patches, and the abandoned field).

Statistical analyses. Failure time analyses were used to determine whether removal rates differed between buried and exposed acorns, and to assess whether removal rates varied across habitat types. We used these non-parametric analyses because they are more robust and accurate than other statistical for comparing this type of binary data. In failure time analyses, acorns are assumed to have a value of 1 at the beginning of the experiment. However, the removal of an individual acorn is considered a 'failure' and its value becomes 0 (zero) at the monitoring time in which the failure is detected. Therefore, for these analyses, each acorn only has two alternatives: it persists until the end of the experiment (i.e., it remains with a value of 1 ) or it is removed by seed consumers (i.e., its value becomes 0 ). At the end of the experiment, removal rates of acorns were estimated with the Kaplan-Meier method (Kaplan and Meier, 1958), and these estimations were used to construct acorn removal curves for each burial level (buried and exposed), each habitat type (patch interior, patch edge, matrix habitat surrounding patches, and abandoned field), and the eight treatments resulting from combining burial levels and habitat types (2 burial levels $\times 4$ habitat types $=8$ treatments). The Gehan's generalized Wilcoxon chi-square test (Aalen et al., 2008) was later used to statistically compare acorn removal curves among factor levels and treatments included in this experiment. No statistical analyses were conducted to compare the occurrence frequency of vertebrates visiting the plots because of the low number of replicates at each habitat type $(\mathrm{n}=2$ per habitat type $)$.

\section{Results}

During the experiment, removal of acorns exposed on the soil surface was registered across monitoring times corresponding to both, day (12:00 and 18:00) and night (00:00 and 06:00). Removal of buried acorns, on the other hand, was only recorded at midnight (00:00) and the predawn (06:00), and it was evidenced by the small holes that seed consumers had dug for recovering these acorns (Figure 2A). No holes indicating removal of buried acorns were detected at midday (12:00) or sunset (18:00).

Mice of the genus Peromyscus (Figure 2B, C) and birds of the genus Aphelocoma (Figure 2D, E) were captured with phototraps while they removed acorns from experimental plots. These two vertebrates were recorded in all habitat types of the study system. However, according to the clocks of phototraps, Peromyscus mice were only recorded during the night, between 21:20 and 05:06, while Aphelocoma birds were only recorded during the daytime, between 07:11 and 17:46.

When removal rates were compared irrespectively of the habitat type in which acorns were located, exposed acorns were removed significantly faster than buried ones $\left(\chi^{2}=\right.$ 38.24 , df $=1, P<0.0001)$. Exposed acorns were started to be removed approximately $18 \mathrm{~h}$ after beginning the experiment, while buried acorns were removed $42-48 \mathrm{~h}$ after this moment (Figure 3A). By the end of the experiment, $83.6 \%$ of acorns that were exposed on the soil surface of the different habitat types included in this study were removed, while only $47.8 \%$ of the buried acorns were taken from experimental plots.

Removal rates also differed among habitat types when they were compared irrespectively of the burial level of acorns $\left(\chi^{2}=1761.50, \mathrm{df}=3, P<0.0001\right)$. Pairwise comparisons between habitat types indicated that acorns located within forest patches and their edges had similar removal rates (Figure 3B). The final percent of removed acorns was $87.4 \%$ at the interior of forest patches and $86.7 \%$ in the edges. These comparisons also shown that acorn removal rates in these two habitat types were significantly higher than those estimated for the matrix habitat surrounding the patches (final percent of removed acorns $=68.6 \%$ ) and the abandoned agricultural field that neighbors the fragmented forest (final percent of removed acorns $=41.7 \%$ ) (Figure 3B). Nevertheless, the removal rate of acorns in the matrix habitat that surrounds the patches was significantly higher than those estimated for the abandoned agricultural field (Figure 3B).

These results suggest that burial level (Figure 3A) and habitat type (Figure 3B) influence removal rates of acorns, but a clearer picture emerged when treatments resulting 

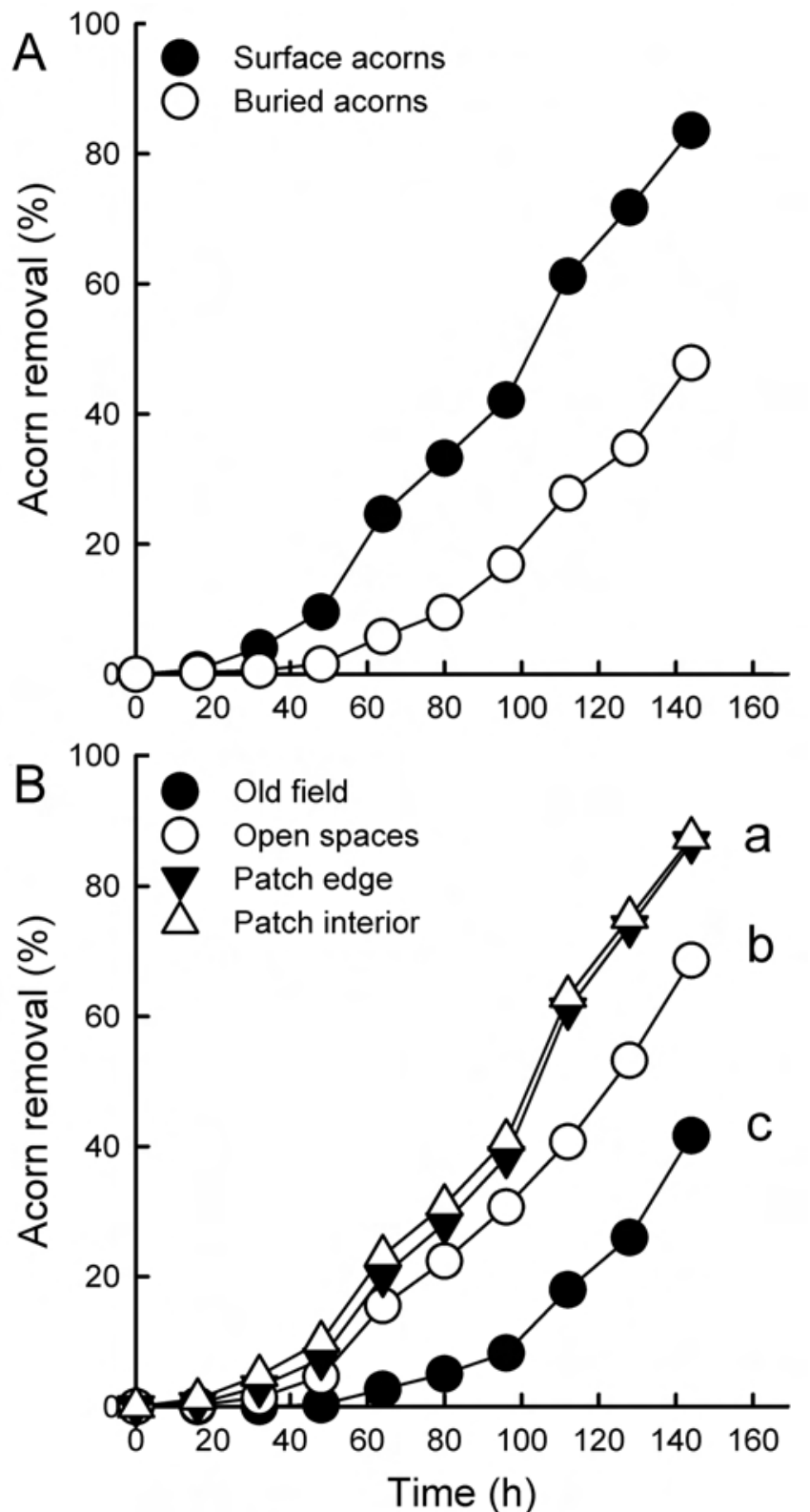

Figure 3. Removal curves estimated with the Kaplan-Meier method. The figure shows the removal curves obtained for buried and exposed acorns irrespectively of the habitat in which they were located (A), and the removal curves obtained at each habitat type irrespectively if acorns were buried or not (B). In panel B, different letters accompanying the curves indicate statistical differences in acorn removal rates between habitat types after performing the respective pairwise comparisons $\left(\chi^{2}\right.$ critical $\left.\alpha=0.05\right)$.

from combining the levels of these two factors were compared (Figure 4). Acorn removal rates significantly differed among these treatments $\left(\chi^{2}=3489.06, \mathrm{df}=7, P<0.0001\right)$. Pairwise comparisons between treatments indicated that, in all habitat types, removal rates of exposed acorns were higher than those estimated for buried ones (Figure 4). Nevertheless, these comparisons also indicated that removal rates of both, buried and exposed acorns, decreased from the interior and edges of forest patches towards the abandoned agricultural field, displaying intermediate values in the matrix habitat that surrounds oak patches (Figure 4).

Removal of exposed acorns at the interior and edges of forest patches, as well as in their surrounding matrix habitat, started $18 \mathrm{~h}$ after beginning the experiment (Figure 4A). In the abandoned agricultural, however, removal of exposed acorns started $42-48 \mathrm{~h}$ after beginning the experiment (Figure $4 \mathrm{~A}$ ). After six days, up to $90.1 \%$ of the acorns exposed on the soil surface were removed from the interior and edges of oak patches. In the matrix habitat surrounding the patches and the abandoned agricultural field these values were $68.8 \%$ and $42.5 \%$, respectively.

In experimental plots from all habitat types, buried acorns showed higher prevalence times than exposed ones. At both, the interior and edges of forest patches, buried acorns were started to be removed $36 \mathrm{~h}$ after beginning the experiment (Figure 4B). The final removal percentages of buried acorns were $83.1 \%$ at the interior forest patches and $78.2 \%$ at their edges. Buried acorns in the matrix habitat surrounding the forest patches were removed later than in the previously mentioned habitat types ( $48 \mathrm{~h}$ after beginning the experiment), and their final removal percent was $35.1 \%$. In the abandoned agricultural field, buried acorns were started to be removed after 78-84 h of experiment and, by the end of the experiment, only $12.9 \%$ of these acorns were removed.

\section{Discussion}

Acorns are the main source of food resources for several small rodents and birds that inhabit oak forests from North America, which quickly consume and/or disperse acorns after they are released from trees and reach the soil (Ostfeld, 2002; Steele and Smallwood, 2002). Nevertheless, most studies on acorn consumption have been focused on acorns exposed on the soil surface, evaluating how vertebrates contribute to reduce their availability in oak forests (e.g., Li and Zhang, 2003; Guzmán-Guzmán and Williams-Linera, 2006; Puerta-Piñero, 2010; Bustamante et al., 2012; Andresen, 2012). On the other hand, studies conducted with buried acorns have been mainly focused in assessing whether burial promote germination and seedling recruitment (e.g., García et al., 2002; Gómez, 2004; Flores-Cano et al., 2012), or whether acorn burial by scatter-hoarding mammals is a mechanism that promote dispersal beyond parental trees (Smallwood et al., 2001; Steele et al., 2001). Therefore, the relevance of acorn burial as a mechanism to evade predation by mammals has received less attention (Haas and Heske, 2005; Muñoz and Bonal, 2011). On this latter issue, our results suggest that buried acorns would be less removed, and they would also be removed later, than acorns exposed on the soil surface (see Figure 3A). This supports the widely accepted proposition that burial may contribute to 

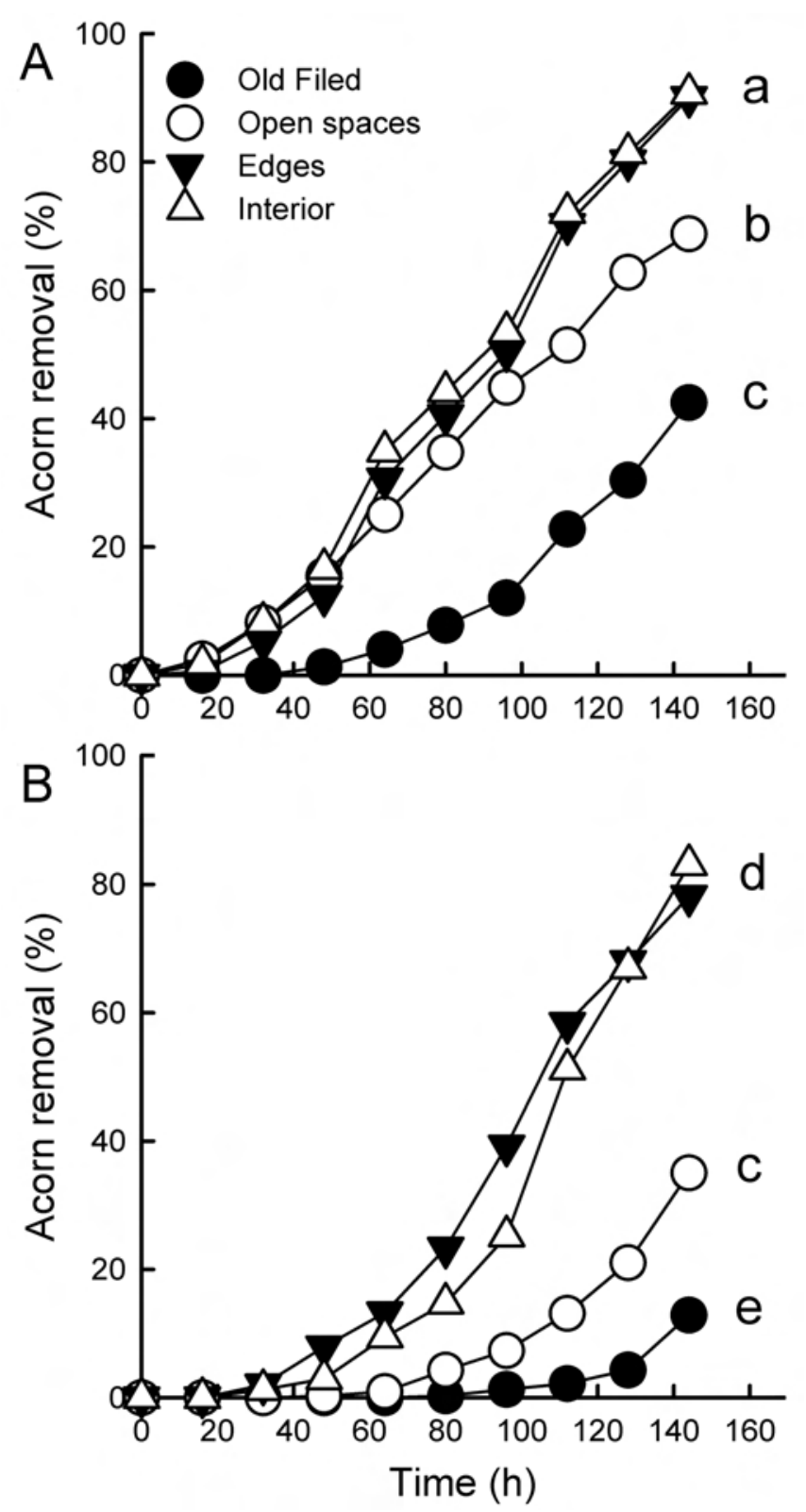

Figure 4. Removal curves estimated with the Kaplan-Meier method for the different combinations of burial levels and habitat types. It is important to note that, in this case, all curves come from a single analysis. Nevertheless, to allow better visual comparisons, curves corresponding to exposed (A) and buried acorns (B) were showed in different panels. Different letters accompanying the curves indicate statistical differences in acorn removal rates after performing the respective pairwise comparisons $\left(\chi^{2}\right.$ critical $\left.\alpha=0.05\right)$.

evade seed predation in forest ecosystems (Janzen, 1971; Andersen, 1989; García et al., 2002; Pinto et al., 2009). Nevertheless, these results also suggest that the outcome of the interactions that take place between acorns and their consumers, as well as the relevance of acorn burial may change across the different habitats composing forest ecosystems that were affected by human activities (see Figure 3B).
Overall, our findings allow proposing that removal rates of exposed (Figure 4A) and buried acorns (Figure 4B) decreased from the interior of forest patches towards the abandoned agricultural field, showing intermediate values in the matrix habitat that surrounds the forest patches. Therefore, acorn removal seems to decrease as the intensity with which human activities affect forest ecosystems increases. In other words, our results suggest that the highest the extension of deforestation, the lowest the impact of predators and/or dispersers on both, exposed and buried acorns. On the other hand, our results also indicated that the differences in removal rates between exposed and buried acorns increased from the interior of forest patches towards the abandoned agricultural field (see Figure 4A, B). Therefore, in the studied landscape, the relevance of burial as a mechanism to evade predation seems rising with increasing extension of forest loss and land use changes induced by human activities. This concurs with the findings of Muñoz and Bonal (2011), which assessed pilferage of acorn catches in a savanna-like landscape of central Spain where oak patches are surrounded by grasslands. These authors showed that scatter-hoarding rodents usually bury their acorn catches in the surrounding grasslands, while they avoid burring catches within oak patches because acorn pilferage by conspecific rodents is higher in this habitat. Indeed, they found larger amounts of emerging seedlings in the grasslands than within the oak patches, and attributed this oak recruitment pattern to the behavior that rodents display for burying their acorn catches (Muñoz and Bonal, 2011). In our case, oak seedlings were neither recorded in the grasslands surrounding the forest patches nor in the abandoned agricultural field, while a few seedlings were observed beneath the canopy of oak patches (Ramos-Palacios, pers. obs.). Nevertheless, more studies should be conducted to assess whether burial, besides contributing to reduce acorn predation risk, effectively promote oak recruitment in our study area.

The intense consumption of acorns at the interior and edges of forest patches could be related to the distribution of consumers across the landscape. In fragmented forest, both granivorous birds and rodents are usually concentrated within the patches because these habitats provide them with refuge from their predators (Tellería et al., 1991; Nupp and Swihart, 2000; Rizkalla and Swihart, 2007). Nevertheless, it is important to note that acorns in the matrix habitat that surrounds the patches, as well as acorns in the abandoned agricultural field that neighbors the fragmented forest, were consumed in lower quantities than acorns located within the patches. This consumption pattern was particularly evident for buried acorns, which were removed even later than exposed acorns in these highly disturbed habitats. This suggests that seed consumers can move across human-modified habitats, and that they consume acorns if they are available in these habitat types. Nevertheless, this also suggests that burial would constitute a more effective mechanism to evade 
predation in highly human-disturbed habitats than at the interior of well-preserved forest patches.

Interestingly, our results indicated that consumption of buried acorns would mainly occur during night. Regarding the animals responsible of generating these acorn removal patterns, phototrapping allows us to propose that Peromyscus mice are the major consumers of buried acorns because these mammals were only recorded during night within the experimental plots. Most mice inhabiting oak forest ecosystems exhibit scatter-hoarding behaviors (Briggs and Smith, 1989; Kirkpatrick and Pekins, 2002; Moore et al., 2007), but they may also steal acorns from catches that other animals have previously buried (Muñoz and Bonal, 2011). Some authors have proposed that the ability of rodents for locating buried acorn catches is linked to olfactory signals of acorns (Steele et al., 2001), and perhaps Peromyscus is using such a strategy for locating the acorns we buried in the study area. Rodents are important consumers and dispersers of acorns in oak forests of North America (Briggs and Smith, 1989; Kirkpatrick and Pekins, 2002). Indeed, Haas and Heske (2005) performed a similar assessment to that conducted in this study in a continuous oak forest of central Illinois (USA), but they indicated that tree squirrels of the genus Sciurus are the main consumer of buried and exposed acorns. However, these authors later avoided the access of squirrels to their experimental plots and found that Peromyscus mice may account for $90 \%$ of acorns exposed on the soil surface of the forest. Nevertheless, they also reported that Peromyscus mice did not consume buried acorns (Haas and Heske, 2005). In our case, no squirrels were detected in the study site and perhaps this was due to the extensive land use changes that affected the forest. However, our results about the consumption of buried acorns contradict to those reported by Haas and Heske (2005) because, besides contributing to remove exposed acorns, Peromyscus mice would be responsible of consuming up to $47.8 \%$ of the acorns that were buried across the different habitat types.

Acorns exposed in the soil surface, on the other hand, were consumed during daytime and night. In this case, phototrapping indicates that both Peromyscus mice and Aphelocoma birds would consume exposed acorns, even when these two groups of vertebrates seem to be active at different moments of the day. As mentioned above, Peromyscus mice would be the main nocturnal consumer of acorns and, therefore, Aphelocoma birds would be the main diurnal consumer of exposed acorns. Birds are important acorn consumers in oak forest of North America (DeGange et al., 1989), but this group of foragers would be the second main guild of acorn removers, after rodents, in European oak forest (Perea et al., 2012). In our case, Aphelocoma birds seems to be important acorn removers in different habitat types of the fragmented forest under study, which is probably linked to their ability to move across the landscape. Indeed, because these birds were suggested to be effective long-distance seed dispersers
(DeGange et al., 1989), they are likely to move acorns from forest patches towards human-impacted habitats. Nevertheless, the importance of mice and birds as acorns disperser across the different habitat types of this fragmented landscape would require more detailed studies.

\section{Acknowledgements}

We thank to Eduarda Muñoz and her family for the support they provided us during the field work. Juan Pablo Rodas, Claudia González, and Omar Samour are acknowledged by their collaboration in the field work. We are also grateful for the valuable comments from two anonymous reviewers which helped to improve the quality of the manuscript. This study was partially founded by project PROMEP/103.5/11/3671.

\section{Literature cited}

Aalen O.O., Borgan Ø. and Gjessing H.K. 2008. Survival and Event History Analysis: A Process Point of View. Springer. New York.

Andersen A.N. 1989. How important is seed predation to recruitment in stable populations of long-lived perennials? Oecologia 81:310-315.

Andresen E. 2012. Dispersión de semillas por animales frugívoros y granívoros. In: del Val E. and Boege K. Coords. Ecología y Evolución de las Interacciones Bióticas, pp. 101-139, Centro de Investigación de Ecosistemas, Universidad Nacional Autónoma de México, Fondo de Cultura Económica, México, D.F.

Arizaga S., Martínez-Cruz J., Salcedo-Cabrales M. and BelloGonzález M.A. 2009. Manual de la Biodiversidad de Encinos Michoacanos. Secretaría de Medio Ambiente y Recursos Naturales. Intituto Nacional de Ecología. México, D.F.

Badano E.I. 2011. Conservation and restoration of Mexican forests in the global change scenario: a shared responsibility with multiple benefits. Madera y Bosques 17:7-18.

Barbeta A., Peñuelas J., Ogaya R. and Jump A.S. 2011. Reduced tree health and seedling production in fragmented Fagus sylvatica forest patches in the Montseny Mountains (NE Spain). Forest Ecology and Management 261:2029-2037.

Bonal R., Muñoz A. and Díaz M. 2007. Satiation of predispersal seed predators: the importance of considering both plant and seed levels. Evolutionary Ecology 21:367-380.

Borchert M.I. and Tyler C.M. 2010. Acorn dispersal of California black oak after a stand-replacing fire. Fire Ecology 6:136-141.

Briggs J.M. and Smith K.G. 1989. Influence of habitat on acorn selection by Peromyscus leucopus. Journal of Mammalogy 70:35-43.

Burgos A., Grez A.A. and Bustamante R.O. 2008. Seed production, pre-dispersal seed predation and germination of Nothofagus glauca (Nothofagaceae) in a temperate fragmented forest in Chile. Forest Ecology and Management 255:1226-1233.

Bustamante R.O., Badano E.I. and Pickett S.T.A. 2012. Impacts of land use change on seed removal patterns of native and exotic species in a forest landscape. Community Ecology 13:171-177.

Cao M., Tang Y., Sheng C. and Zhang J. 2000. Viable seeds buried in the tropical forest soils of Xishuangbanna, SW China. Seed Science Research 10:255-264. 
Crawley M.J. and Long C.R. 1995. Alternate bearing, predator satiation and seedling recruitment in Quercus robur L. Journal of Ecology 83:683-696.

DeGange A.R., Fitzpatrick J.W., Layne J.N. and Woolfenden G.E. 1989. Acorn harvesting by Florida scrub jays. Ecology 70:348-356.

Fagan W.F., Cantrell R.S. and Cosner C. 1999. How habitat edges change species interactions. American Naturalist 153:165-182.

Flores-Cano J., Badano E.I. and Flores J. 2012. Effects of burial depth on seed germination and seedling emergence of Mexican oaks: a glasshouse experiment. Archives of Biological Sciences 64:1543-1554.

García D., Bañuelos M.J. and Houle G. 2002. Differential effects of acorn burial and litter cover on Quercus rubra recruitment at the limit of its range in eastern North America. Canadian Journal of Botany 80:1115-1120.

García D., Obeso J.R. and Martínez I. 2005. Rodent seed predation promotes differential recruitment among bird-dispersed trees in temperate secondary forests. Oecologia 144:435-446.

Gómez J.M. 2004. Importance of microhabitat and acorn burial on Quercus ilex early recruitment: non-additive effects on multiple demographic processes. Plant Ecology 172:287-297.

Guzmán-Guzmán J. and Williams-Linera G. 2006. Edge effect on acorn removal and oak seedling survival in Mexican lower montane forest fragments. New Forests 31:487-495.

Haas J.P. and Heske E.J. 2005. Experimental study of the effects of mammalian acorn predators on red oak acorn survival and germination. Journal of Mammalogy 86:1015-1021.

Herrerías-Diego Y., Quesada M., Stoner K.E., Lobo J.A., Hernández-Flores Y. and Sanchez M.G. 2008. Effect of forest fragmentation on fruit and seed predation of the tropical dry forest tree Ceiba aesculifolia. Biological Conservation 141:241-248.

Hulme P.E. and Borelli T. 1999. Variability in post-dispersal seed predation in deciduous woodland: relative importance of location, seed species, burial and density. Plant Ecology 145:149156.

Jacobs L.F. and Liman E.R. 1991. Greys squirrels remember the locations of buried nuts. Animal Behavior 41:103-110

Janzen D.H. 1971. Seed predation by animals. Annual Review of Ecology and Systematics 2:465-492.

Kaplan E.L. and Meier P. 1958. Nonparametric estimation from incomplete observations. Journal of the American Statistical Association 53:457-481.

Kelly D. and Sork V.L. 2002. Mast seeding in perennial plants: why, how, where? Annual Review of Ecology and Systematics 33:427-447.

Kirkpatrick R.L. and Pekins P.J. 2002. Nutritional value of acorns for wildlife. In: McShea W.J. and Healy W.M. Eds. Oak Forest Ecosystems: Ecology and Management for Wildlife, pp. 173181, The Johns Hopkins University Press, Baltimore.

Leverkus A.B., Castro J., Puerta-Piñero C. and Rey B.J.M. 2013. Suitability of the management of habitat complexity, acorn burial depth, and a chemical repellent for post-fire reforestation of oaks. Ecological Engineering 53:15-22.

Li H.J. and Zhang Z.B. 2003. Effect of rodents on acorn dispersal and survival of the Liaodong oak (Quercus liaotungensis Koidz.). Forest Ecology and Management 176:387-396.

Llorente-Bousquets J. and Ocegueda S. 2008. Estado del conocimiento de la biota. In: Sarukhán J., Soberón J., Halffter G., Llorente-Bousquets J. Comps. Capital Natural de México. Vol. I:
Conocimiento Actual de la Biodiversidad, pp. 283-322, Comisión Nacional para el Conocimiento y Uso de la Biodiversidad, México, D.F.

Lund H.G., Torres V., Turner A. and Wood L. 2002. México: Análisis Crítico de los Estimados Disponibles de Deforestación. United States Agency for International Development, Secretaría de Medio Ambiente y Recursos Naturales. México, D.F.

Martínez Chaves P.A., Betancourt Mendieta A., Nicolás Caretta M. and Aguilar Robledo M. 2010. Procesos históricos y ambientales en Cerro de San Pedro, San Luis Potosí, México, 1948-1997. Región y Sociedad 22:211-241.

McCormick J.T. and Meiners S.J. 2000. Season and distance from forest-old field edge affect seed predation by white-footed mice. Northeastern Naturalist 7:7-16.

Meiners S.J. and LoGiudice K. 2003. Temporal consistency in the spatial pattern of seed predation across a forest-old field edge. Plant Ecology 168:45-55.

Moore J.E., McEuen A.B., Swihart R.K., Contreras T.A. and Steele M.A. 2007. Determinants of seed removal distance by scatterhoarding rodents in deciduous forests. Ecology 88: 2529-2540.

Muñoz A. and Bonal R. 2011. Linking seed dispersal to cache protection strategies. Journal of Ecology 99:1016-1025.

Nupp T.E. and Swihart R.K. 2000. Landscape-level correlates of small-mammal assemblages in forest fragments of farmland. Journal of Mammalogy 81:512-526.

Ostfeld R.S. 2002. Ecological webs involving acorns and mice: basic research and its management implications. In: McShea W.J. and Healy W.M. Eds. Oak Forest Ecosystems: Ecology and Management for Wildlife, pp. 196-214, The Johns Hopkins University Press, Baltimore.

Pedraza M.J.F. 1994. Sinopsis Histórica del Municipio de Cerro de San Pedro del Estado de San Luis Potosí. Centro de Desarrollo Municipal. San Luis Potosí.

Perea R., San Miguel A, Martínez-Jauregui M., Valbuena-Carabaña M. and Gil L. 2012. Effects of seed quality and seed location on the removal of acorns and beechnuts. European Journal of Forest Research 131:623-631

Pinto S.R.R., Santos A.M.M. and Tabarelli M. 2009. Seed predation by rodents and safe sites for large-seeded trees in a fragment of the Brazilian Atlantic forest. Brazilian Journal of Biology 69:763-771.

Puerta-Piñero C. 2010. Intermediate spatial variations on acorn predation shapes Holm oak establishment within a Mediterranean landscape context. Plant Ecology 210:213-224.

Rizkalla C.E. and Swihart R.K. 2007. Explaining movement decisions of forest rodents in fragmented landscapes. Biological Conservation 140:339-348.

Rocha O.J. and Aguilar G. 2001. Reproductive biology of the dry forest tree Enterolobium cyclocarpum (guanacaste) in Costa Rica: a comparison between trees left in pastures and trees in continuous forest. American Journal of Botany 88:16071614.

Smallwood P.D., Steele M.A. and Faeth S.H. 2001. The ultimate basis of the caching preferences of rodents, and the oak-dispersal syndrome: tannins, insects, and seed germination. American Zoologist 41:840-851.

Smith C.C. and Stapanian M.A. 2002. Squirrels and oaks. In: McShea W.J. and Healy W.M. Eds. Oak Forest Ecosystems: Ecology and Management for Wildlife, pp. 256-266, The Johns Hopkins University Press, Baltimore. 
Sork V.L. 1983. Distribution of pignut hickory (Carya glabra) along a forest to edge transect, and factors affecting seedling recruitment. Bulletin of the Torrey Botanical Club 110:494-506.

Steele M.A. and Smallwood P.D. 2002. Acorn dispersal by birds and mammals. In: McShea W.J. and Healy W.M. Eds. Oak Forest Ecosystems: Ecology and Management for Wildlife, pp. 182-195, The Johns Hopkins University Press, Baltimore.

Steele M.A., Smallwood P.D., Spunar A. and Nelsen E. 2001. The proximate basis of the oak dispersal syndrome: detection of seed dormancy by rodents. American Zoologist 41:852-864.

Steffen D.E., Lafon N.W. and Norman G.W. 2002. Turkeys, acorns, and oaks. In: McShea W.J. and Healy W.M. Eds. Oak Forest Ecosystems: Ecology and Management for Wildlife, pp. 241255, The Johns Hopkins University Press, Baltimore.
Studnicki-Gizbert D. and Schecter D. 2010. The environmental dynamics of a colonial fuel-rush: silver mining and deforestation in New Spain, 1522 to 1810. Environmental History 15:94119.

Tellería J.L., Santos T. and Alcántara M. 1991. Abundance and food-searching intensity of wood mice (Apodemus sylvaticus) in fragmented forests. Journal of Mammalogy 72:183-187.

Vaz Ferreira A., Bruna E.M. and Vasconcelos H.L. 2011. Seed predators limit plant recruitment in Neotropical savannas. Oikos 120:1013-1022.

Vesk P.A., Davidson A. and Chee Y.E. 2010. Spatial distribution and prediction of seed production by Eucalyptus microcarpa in a fragmented landscape. Austral Ecology 35:60-71.

Received: June 11th, 2013

Accepted: August 12th, 2013 